\title{
Into the First League: The Competitive Advantage of the Antivirus Industry in the Czech Republic and Slovakia
}

\author{
Miroslav Beblavý \\ Center for European Policy Studies, Brussels, Belgium and Comenius \\ University, Bratislava, Slovakia \\ Lucia MÝtNa Kureková \\ Slovak Governance Institute, Slovakia
}

The antivirus industry is the only innovation-intensive sector in which homegrown companies from Central Europe have been able to gain and retain global leadership. We review the literature on sources of national competitive advantage and evaluate the relative importance of different factors, drawing on evidence gained from semi-structured interviews with key stakeholders and existing research about the IT sector's global and regional trends. Highly-skilled, technical human capital played a crucial and positive role. Paradoxically, a lack of available foreign finance also had a positive impact by steering the best people towards a sector with smaller capital needs. Unlike other leading sectors in Central Europe, where state support and foreign capital were important, these factors were absent in this sector. This article contributes to understanding of the emergence of a home-grown, highly competitive, high-technology sector under the conditions of market transformation, liberalization and internationalization in small economies.

KEYWORDS antivirus industry, competitive advantage, human capital, innovation, Slovakia

\section{Introduction}

The antivirus industry is part of the most sophisticated and technologically demanding segment of the software sector. This research was inspired by an intriguing observation that three domestically-grown antivirus companies from the former Czechoslovakia ${ }^{\mathrm{T}}$ have occupied leading positions in world markets. With market shares of I6, II and Io per cent, respectively (OPSWAT, 2012), ${ }^{2}$ their position has been stable over time. 
Their success can largely be attributed to the ability to continually and genuinely innovate, which can be seen through repeated international recognition of the quality of their products by independent evaluators. No other home-grown sector in Central Europe has experienced similar global success. The region's economic success has been based almost exclusively on foreign direct investment (FDI) and integrating into the global supply chains of multinational corporations (MNCs), mainly in the automotive and electronics sectors (Bohle \& Greskovits, 2007; Myant \& Drahokoupil, 20Irb; Pavlínek et al., 2009). We therefore find it important to better understand and evaluate the factors that have contributed to the global success of the antivirus sector and to derive more general lessons about the sources of national competitive advantage in small, highly internationalized and open economies. By gathering rich empirical data through semi-structured interviews with various stakeholders, we are able to see the sector from different perspectives, including those of venture capital investors, public officials, the CEOs of domestic and foreign companies and heads of human resources (HR). We construct the development trajectories of firms and discuss key factors in their growth and expansion process. Even though the case study approach has its limits, we believe that in this particular instance it is robust. First, antivirus firms were originally established in nearly all Central and Eastern European countries, but only three from Central Europe have succeeded to such an extent. Second, all three firms were founded during a similar period, with similar long-term success, but through very different trajectories. This, then, excludes the major role of firm-level idiosyncrasy as a determinant of success, and points to the relevance of structural factors and global economic trends. To the best of our knowledge, no other work has so far systematically evaluated the conditions under which a home-based highly competitive segment of the high-technology sector has emerged and succeeded, as most academic and policy attention to date has been devoted to the study of the presence of MNCs in Central Europe.

The article is organized as follows. In the second section we briefly discuss different bodies of literature studying sources of national competitive advantage and determinants of innovative capacity, and position these against regional works describing leading economic sectors. The third section outlines the general trajectory of the software industry and the fourth demonstrates the growing importance of the IT industry in the Czech and Slovak economies. The fifth section concentrates on a detailed presentation of three company case studies. In the sixth section we use the empirical findings to address questions regarding the source of national competitive advantage. The final section summarizes the argument and concludes.

\section{National competitive advantage}

This section outlines the literature that informs our conceptual framework. Determinants of country-level innovation and competitive advantage have been exhaustively studied (Bhidé, 2008; Gereffi, I994; Hidalgo \& Hausmann, 2009; Porter, I990). Bhidé (2008) examines the evolution of new companies in innovative industries in the US supported by venture capital and emphasizes the importance of consumer- rather than producer-driven innovation. Hidalgo and Hausman (2009) link complexity of a country's production to the level of economic development and show that different capabilities, measured through existing production, are needed to move up to more 
complex products. Gereffi (I994) focuses on explaining the logic of the organization of production between buyer- and producer-driven commodity chains and the localization of high-end production and its resulting innovation.

Despite its weaknesses, which are briefly outlined below, we use Porter's competitiveness framework as the main conceptual framework for organizing our empirical findings. Porter's framework has been proposed as a tool to explain the competitive advantage of nations, industries and firms (Porter, I990, 2000). His model is based on four country-specific determinants (basic and advanced factor endowments; demand conditions; related and supporting industries; and firm strategy, structure and rivalry) and two external factors (chance and the role of government). These factors interact and intervene, creating a systemic environment wherein the quality of these interactions determines the competitive advantage and success of industries in global markets. In particular, Porter emphasizes the importance of the 'home base' and posits that it 'will be the location of many of the most productive jobs, the core technologies and the most advanced skills' (Porter, I990: 77).

From our point of view, Porter's approach is flexible and comprehensive, but its predictions and expectations have been built on the experience of large economies with a strong home base and domestic demand, and it has several other limitations. First, Porter's diamond framework appears less relevant for the small, open and internationalized economies of the Czech Republic and Slovakia (Clancy et al., 200I; Davies \& Ellis, 2000; Rugman \& D'cruz, I993; Smith, 20I2). Second, his focus on geographical concentration of companies as an essential factor supporting internal competition and innovation has been criticized and further elaborated. Boschma (2005) and Boschma and Frenken (20I0) elaborate on different types of proximity (social, cognitive, organizational and institutional), which can contribute to effective co-ordination among firms and to interactive learning and innovation. In the same vein, Enright (2003) offers a complex theoretical understanding of clustering that includes a set of factors and conditions inhibiting the positive impact on innovation.

Third, concentrating on domestic rivalry, Porter highlights the negative role governments can play by generating distortion in the competitive environment by, for example, choosing national champions and shielding the growth of domestic industries. Studies of Central Europe have argued for a key role of the state in spurring the success of the region's leading sectors (automotive and electronics industries) and in the process of the region's integration into the global economy (Bernaciak \& Šcepanovic, 20Iо; Bohle \& Greskovits, 2007; Duman \& Kureková, 20I2). Government efforts to attract foreign capital and stimulate upgrades have interacted with the importance of inherited factor conditions, mainly the availability of cheap, docile and skilled labour, geographical closeness to EU markets and political stability in view of the region's integration into the EU (Bohle \& Greskovits, 20I2). In the following sections, we therefore highlight where our findings are in line with Porter's framework and where they depart or contradict it.

Generally, studies that hypothesize an explicit link between national institutional context and innovation target mainly advanced economies (Bassanini \& Ernst, 2002; Hall \& Soskice, 200I; Toner, 20II). Hall and Soskice (200I), in particular, highlight the impact of institutional complementarities on the competitiveness of their two socio-economic model prototypes - co-ordinated market economies (CMEs) and liberal market economies (LMEs). While CMEs tend to excel in specific skills and 
incremental innovation, in LMEs general skills and radical innovation prevail. Regionally specific works on socio-economic models of capitalism in Central and Eastern Europe have demonstrated that institutional frameworks that have evolved as an outcome of the transition are sui generis and cannot be directly compared to the advanced economies (Bohle \& Greskovits, 2007, 20I2; Duman \& Kureková, 20I2; Myant \& Drahokoupil, 20ııa; Nölke and Vliegenthart, 2009). Analytical investigation of the domestically-grown, but globally successful, antivirus industry can therefore enrich regionally focused works as well as more general frameworks studying sources of national competitive advantage.

\section{The context of the IT industry}

The IT industry is a high value-added sector in which the most important input is highly skilled, qualified and innovative labour. ${ }^{3}$ It is characterized by one of the fastest product life cycles, in which the life span of new software applications can be as little as two to three years (Bell, I995). Therefore, a continual and high degree of product innovation is necessary for a given company to continue generating profit (Tsai et al., 2009). The need for a rapid and flexible response to changing market dynamics is reflected in the way work and employment is organized (Benner, 2002; Grimes \& White, 2005; Wickham \& Bruff, 2008).

For innovation-intensive high-tech industries, human capital is a key resource. Its quality and availability are crucial and lack of it can create problems for a firm's sustainability and growth. Relative to capital-intensive industries, such as the automotive sector, large capital investments are of lesser importance, at least at the initial stage of establishing a firm or a new product. The availability of capital plays an important role at a point when a company seeks to grow and establish itself on the world market. Being a high-risk high-profit sector, the IT industry is typically a target of different types of private capital (venture capitalists, angel capitalists and private equity funds) rather than being supported by 'patient' bank money or public resources.

Over the last two decades, the computer and software industry has been characterized by internationalization and diversification. First, with the spread and availability of internet connections, IT and computer services companies turned away from serving traditionally limited national markets to providing services more effectively in an open and global market space. The globalization of demand and supply has been taking place simultaneously (Coe, I997). The internationalization of major manufacturing firms was one of the key trends that spurred the expansion of IT and computer services, which typically follow their clients to new destinations (Coe, I997; Grimes \& White, 2005; Guzik \& Micek, 2008); this trend has been typical of the Central and Eastern European region (Capik \& Drahokoupil, 20II). Additional factors that have contributed to the rapid internationalization of the ICT industry since the I990s have been declining language barriers as a result of the dominance of English, the standardization of hardware, the increasing compatibility of existing systems and the introduction of international computing standards (Coe, I997; Micek, 2008). A general shortage of skilled IT professionals in the US and Western Europe might be concomitant factors contributing to the internationalization and 'delocalization' of the IT sector (Guzik \& Micek, 2008). More generally, internationalization has been a response to the demand for extensive client support in terms of consultancy, systems 
design, customization, installation, training, upgrading and after-sales service, and has been accompanied by a second major trend in the industry — the diversification of the products and services offered (Bell, I995).

Second, diversification began with the hardware producers extending to software and services (Coe, 1997) and has continued with further advances in the provision of integrated services, such as 'security suites' or 'cloud computing'. Such a development has also been described as 'service encapsulation', implying that services are embedded in products and there is a close interlinkage between products and services (Grimes, 2006). Unlike global companies providing computer services, small software firms normally offer highly specialized services or products targeted at narrow niches (Bell, I995). Furthermore, small and medium-sized software enterprises tend to internationalize very rapidly rather than in small incremental steps (typical for manufacturing). The possibility of selling products online further decreases 'export' costs and the time to market a product, and revolutionizes the possibilities of and approaches to PR and marketing.

The evolution of the service sector is also reflected in the statistical redefinition of software, which prior to the spread of the internet was delivered as a physical product, but is now offered electronically and may be delivered as part of an overall package that includes an array of other services (Grimes, 2006). This is in stark contrast to the original definition of a service activity, defined as an intangible, non-storable and non-transportable output consumed and bought at the moment of its production and thus requiring a physical proximity between producer and consumer (Sass \& Fifekova, 20II). This de-linked and re-shaped nature of 'proximity' in the computer services industry, defined by availability and appropriate competence rather than physical presence, has important implications for a more diffused localization of employment in certain segments of the industry, including the higher value-added activities such as software development and R\&D generally.

While follow-the-client behaviour of large ICT firms implies a specific 'geography of employment', whereby the location of client firms determines the location of computer services companies (Coe, I997), this logic of localization is not necessarily valid in the case of software companies focused on innovation or knowledge creation. Innovative firms in the sector, such as the antivirus companies analysed in this article, follow, rather, an internationalization model in which mergers and acquisitions (M\&As) are guided by strategic decisions in acquiring essential complementary knowledge to the current or envisaged expertise in the firm (Coe, I997). This supports a more horizontal organization of highly sophisticated activities in multiple locations, driven by the fact that fast-growing IT or knowledge-based activities are highly dependent on the availability of a sufficient volume of high quality human capital. Fast-growing companies quickly reach the limits within local economies (especially small ones) and turn to the establishment of R\&D centres globally (Agarwal \& Pandey, 2004).

\section{The IT sector in Central Europe: Moving upwards}

The growth of the IT sector in the Czech and Slovak economies has been most apparent since the mid-200os (Čapek, 20I2). Prior to that, software and computer 
services markets were initially unattractive to foreign investors owing to the costs and difficulties of translating products for different local markets, the fear of political instability and a general lack of trust related to the very high level of software piracy. During the I990s, the production of computer hardware was increasing, but purchasing power of users and businesses for the most part was not sufficient to create a large demand for additional software. An additional factor was the perceived character of the whole post-communist region as a bed of production for malware and viruses (Coe, I997; Třešňák, 2007). The expansion of the IT sector in Central and Eastern Europe took place in parallel with the more general processes happening globally. In line with international trends, the structure of FDI in Central and Eastern Europe diversified from manufacturing FDI to include also service sector FDI in the early 2000 s.

Incoming IT companies initiated their presence through offshoring lower valueadded services, such as back-office, corporate functions and customer care (Capik \& Drahokoupil, 20II; Hardy et al., 20II; Piech \& Radosevic, 2006). However, with the prolonged presence of IT companies in the region, regardless of the initial motives for entry, an awareness of the availability of skilled and talented labour attained through interaction with the local labour market led to the localization of more sophisticated activities. Among them were shared service functions (accounting and finance), IT support and IT problem-solving centres (Hardy et al., 20II) and several R\&D centres. ${ }^{4}$ A gradual shift towards a greater share of high value-added activities has been influenced by the discovery of the human capital potential in these countries (Sass \& Fifekova, 20II). In the late 2000 s and prior to the economic crisis of 2008-09, the quest for qualified labour was intense and many references alluding to the shortage of qualified IT workers were made (Lauder, 20IO; SME, 2008).

Recently, the software sector has been increasingly characterized by the emergence of start-ups, especially in the Czech Republic (Kočí, 20I2; Lauder, 20IO). The efforts of government agencies and private initiatives (or their co-operation) to support the start-up scene have grown apace. An important characteristic of several IT R\&D centres established in the Czech Republic or in Slovakia is that a foreign investor was involved in developing them by acquiring or expanding an existing successful domestic company - a phenomenon that can be dubbed 'offshore R\&D'.

\section{Trajectories of antivirus firms in Czech Republic and Slovakia}

The antivirus industry forms part of the most sophisticated and technologicallydemanding segment of the software sector. The need for innovation is continuous, but also more incremental and based largely on previously acquired knowledge and experience. Antivirus software is a product that requires very deep and difficult-toemulate expertise of only a relatively limited number of people. The product development cycle is long, which requires the availability of patient rather than aggressive venture capital, although the capital intensity of the sector compared with other high-tech industries is lower. From the perspective of innovation type, the antivirus segment lies in-between radical and incremental innovation, which makes it difficult to propose a direct theoretical link to the 'ideal' institutional framework that would support such innovation (cf. Bassanini \& Ernst, 2002; Toner, 20II). 
The security software market has followed a similar trajectory to that of general software internationalization. During the process of relative global market consolidation, a number of regional companies in Central and Eastern Europe were acquired by a larger competitor (e.g. the acquisition of Romanian GeCad by Microsoft (Microsoft, 2003). The antivirus segment of the software industry currently consists of I 5-20 companies. Two Czech companies, AVAST and AVG, and the Slovak ESET resisted this global consolidation process and have gained a stable position among the five most successful vendors of security software in the world, while keeping the home-base and key R\&D activities in domestic economies. In $20 \mathrm{I} 2$ they jointly possessed a share of about 37 per cent of the world market (I6, II and Io per cent, respectively) (OPSWAT, 20I2). We can distinguish three essential and partially overlapping stages in the development of the firms. These help us to identify the key factors at different stages of the firms' growth and internationalization, which we then evaluate against broader theoretical frameworks.

\section{Phase 1: Establishment and stabilization}

In the first stage, during the late I980s and I990s, the firms were founded and antivirus programs were sold in national markets. AVAST (originally ALWILL) ${ }^{6}$ was established in 1988 by two Czech programming innovators based at a research institute in Prague, as a production co-operative to write the first antivirus program able to remove the Vienna virus (Komárek, 2008). The antivirus program was initially sold in boxes as a physical product, and the sales and marketing strategy was orientated towards large firms and the public sector in the Czech Republic. AVG (originally GRISOFT) was formed in 1989 in Brno. The first antivirus product was introduced in the local market in I992. In I994, a decision was made to specialize in antivirus software alone. ESET dates back to I987, when two programming engineers discovered one of the first viruses and wrote a program able to detect it. By I990, the firm had already offered the initial version of a program called STOPVIR to the Austrian market. ESET was formally established in I992.

Home market demand after the firms' establishment was crucial for all three firms, but in a different manner to that proposed by Porter. He emphasizes the sophistication of domestic consumers as a spur for innovation. In these cases, the home market was important, as it provided a space wherein the products could be tested and developed and from where sufficient income could be generated to enable a process of improving the antivirus software to the point of its gaining international recognition in terms of quality. The second paradoxical, but important, contribution made by the firms' location in Central Europe was the fact that, early on, the software producers in the region were unattractive to private equity and foreign investors owing to perceived political instability, low purchasing power and the poor reputation of the region. In addition, many foreign firms active in niche markets such as antivirus software were unwilling to offer their products in national languages, which created a lack of foreign competition that could have potentially been destructive for domestic antivirus firms. The combination of these factors provided a period of shielded growth for domestic firms and also relieved the pressure to consolidate that was taking place in the segment worldwide. ${ }^{7}$ While informal discussions about the possible consolidation of the three firms took place, they were never seriously 
followed up. The three firms coexisted under effective market segmentation (homeend users versus corporate clients; different foreign markets), a process that took place naturally rather than by agreement and is related to the next stage of the firms' trajectory. ${ }^{8}$

What we observe from the firms' early establishment is that initiatives had already begun prior to the fall of communism in I989. Then, Czechoslovak IT entrepreneurs started to develop their products in the parochial conditions of a closed economy. Until the early 2000s, the ownership and employment structure of all three companies was nearly exclusively Czech and Slovak. None of the founders or early top managers was an expatriate or a repatriate. In this sense, the Czech and Slovak antivirus industry is very much an indigenous creation. This is in contrast to Israel, where long-standing business and personal links to US ICT companies were vital (Singer \& Senor, 20II) or to the Irish software industry, whose repatriated workforce was a key impetus in the growth of the multinational software industry there (Grimes \& White, 2005; White, 2004).

\section{Phase 2: Internationalizing markets}

In the second stage, a greater internationalization of markets began in the second half of the I990s and dramatically evolved in the 2000 s. It was both a response to a saturation of domestic markets (Andacky, 2004; Koubský, 2000; Respect, 2000) and a reaction to the wider spread of the internet, which took place earlier abroad than in the firms' home countries. All three companies expanded their product portfolios from antivirus programs to the full protection of computers, including malware and spyware detection, and the protection of other durables such as mobiles. Importantly, with the spread of the internet, becoming internationalized in the antivirus sector does not require building physical infrastructure in the target markets, but rather involves sophisticated PR and business strategies that ensure the product is known and purchased by clients. Becoming aware of this, AVG and AVAST turned to the freemium business model, and ESET invested heavily in marketing and branding campaigns at home and abroad.

For AVAST, a crucial growth factor during the I990s was co-operation with McAfee, which began using the AVAST antivirus engine and further licensed it for use in its line of products. Such a partnership was key, not only in providing further marketing and evidence of product quality but also in terms of revenue, which helped the company to survive the difficult years surrounding the dotcom bubble and to finance the introduction of the 'freemium' model in 200I. Free AVAST for home endusers was introduced partly as a result of a lack of capital for international marketing. It proved very successful as a user community-based model, which increased the firm's visibility in world markets. A further spur to growth came in the form of a strategic alliance with SanDisc, which offered the AVAST antivirus product on its USB sticks. This again served as a way to bring the product to more clients, but with retrospect an even more important side effect was the requirement of SanDisc that AVAST offer support in multiple languages. This triggered the internationalization of sales staff within the company.

AVG began to offer an English version for free in 1995. This enabled it to enter the market with relative success, especially in the UK. Similar to AVAST, in the late I990s AVG offered its licences abroad and in diverse destinations (Germany and the 
UK). Furthermore, in I998 AVG was introduced to the US market by establishing Grisoft Inc. in Delaware. AVG then started building an international network of distributors and resellers to provide services worldwide, accompanied by launching the freemium model (Respect, 2000).

The establishment of ESET's sales point in San Diego in I999 was preceded by an investment in the development of a new version of its program in I995, following which ESET gained international recognition for the quality of its products. In the early 2000s, the firm made a further technological leap that raised its profile with respect to the quality of its antivirus product. During the I990s, the firm targeted domestic corporate customers (mainly small and medium-sized enterprises) and this orientation has remained crucial to date. This has been identified as a key reason why ESET never followed its competitors in the region who were using the freemium model. Interestingly, the San Diego sales point was brought back to Bratislava in 2009 .

With regard to the internationalization of products and markets, the small size of the domestic market pushed the antivirus firms to internationalize during the second half of the I990s. In larger markets such as the UK, Germany, Spain and Poland, domestic market size provided less of an immediate impetus to expand beyond national borders. Hungary's greater openness to FDI also affected the IT sector and early on led to the acquisition of a domestic champion. ${ }^{9}$ This coincided with the rapidly decreasing costs of internationalization resulting from the internet, which provided an easy distribution medium for antivirus companies and changed business and distribution models to those that were friendly to Czech and Slovak companies.

\section{Phase 3: Internationalization of ownership and management}

In the third stage, an internationalization of ownership and management took place. AVG was the 'first-mover' and has gone furthest. When the key founder exited the company in the early 2000s, he invited a professional manager to manage the firm with an explicit agenda to expand into global markets. The investor that initially acquired the firm persistently pushed to make AVG a global player, a move further intensified by the entry of large private equity funds. The journey to the New York Stock Exchange entailed hiring an American CEO and a gradual complete internationalization of the management and board of the company. This was further accompanied by an aggressive and proactive M\&A strategy with promising start-ups across the world, with the goal of diversifying the firm's portfolio into further niches and tapping into new trends, such as a complex protection of security suites, and the protection of mobiles and androids. AVG has built an image based on the typical US company, transforming it from a small family-based firm with informal relations to a profit-orientated international organization with global ambitions (Orfanus, 20I2). However, AVG maintains its managing headquarters in Prague and technology headquarters in Brno, where it was originally established.

A major change in the governance of AVAST was the professionalization of its management board, and especially the hiring of a CEO of US origin in 2009, who came from a key competitor (Symantec). The management board has since become more internationalized, while managers of Czech origin continue to occupy about half of management positions. The hiring of an external CEO led to major growth in both employment and the consumer base. AVAST sold a minority stake in 20 Io to 
Summit Partners, a US-based private equity fund. The ownership restructuring process was crowned by a decision to file an application for stock market listing in the US in $20 \mathrm{I} 2$.

The management remains mixed - Czech and international - and the company portrays itself as a Czech-based and Czech-origin firm. Unlike AVG, the investor does not directly affect the management of the firm, but has played a key role with respect to strategic advice and ties to Silicon Valley. While AVAST has also carried out a few M\&As abroad, these appear to have been responsive rather than proactive, and aimed mainly at acquiring human capital in competitor firms in nearby countries (hence branches in Germany and Austria). This is related to a declared strategy of developing products internally in its key R\&D base in Prague, rather than 'buying' knowledge through M\&As. AVAST intentionally placed a large sales support centre in the Czech Republic, where multiple nationalities were hired to serve the international client base: 'Prague has a great location, it is beautiful, it is not a problem to get people from all over the world to come here. We do not need Silicon Valley. The quality is the same but people and rents are more expensive' (Komárek, 2008).

The ambitions and approach of the founders and key owners of the Slovak ESET towards expansion diverge significantly from the paths of the two Czech firms. ESET has never allowed the entry of private equity capital or internationalized its management. The company co-founders claimed that interested parties were only seeking a short-term investment orientated towards quick exit (Andacky, 2004). So far, ESET remains privately owned.

Only in the late 2000 s did the founders begin to seek professionalized management in order to devote more time to strategic thinking and planning (Jarosova, 2008). Suspicions about the US model of management and the implications of a shared ownership structure for company decisions seemed to deter the founders from such steps (Andacky, 2009).

ESET has chosen a foreign market penetration strategy based on the establishment of sale points on several continents (San Diego, US; Wexford, Ireland; London, UK; Buenos Aires, Argentina; Prague, Czech Republic; Singapore), accompanied by intensive marketing efforts. The M\&A strategy has been modest, with self-financed acquisitions of a network security company in 2008 and an anti-spam company in 20 IO. Product diversification and expansion to complex security suites or diversification into the protection of Linux products for corporate clients is based on product development conducted mainly in Bratislava- and Kosice-based R\&D units, and recently also in Krakow (Jarosova, 2008).

All three firms have followed a similar strategy with respect to the internationalization of lower-level human capital and localization decisions. As a result of the bureaucratic difficulties of recruiting human capital from outside the European Union (from the former Soviet Union), an alternative strategy was pursued - buy-outs of start-up companies that fit into the firms' portfolios (AVG and ESET) or the establishment of smaller R\&D branches elsewhere (ESET and AVAST). Importantly, technological acquisitions have often been driven by the need to acquire good people as much as by the products themselves. The core R\&D has generally been maintained at the home base, even after the process of internationalization. 


\section{Evaluating national competitive advantages in the antivirus industry}

\section{Factor conditions}

We have identified two crucial advanced factor conditions - sufficient human capital and, paradoxically, limited sources of finance for innovative companies. First, domestic expertise and technical skills existing in these countries at the end of the I980s - and their sufficient supply since then - have been critical for the initial establishment and continued growth of the companies. The key competitive advantage of the Czech and Slovak firms has been the technological quality of staff rather than skills in management, marketing and sales, a legacy of highly-skilled technical human capital inherited from the communist regime. This is evidenced by a combination of international awards at an early stage of their development and the use of their antivirus engines by foreign firms.

The strategies employed by these firms with respect to their employees have responded to the importance of human capital as an asset. In all three companies, employees are highly valued and offered permanent and stable work contracts, high pay and other social benefits and advantages, which has led to a low turnover of technical staff in particular. The firms' global success has made them attractive for potential employees and therefore very successful in recruitment. To ensure continued ease of hiring, the companies have gone to great lengths to develop a specific firm identity. In addition, the firms have taken a very strategic approach to ensuring consistent inflows to 'fill the pipeline' by actively seeking co-operation with universities. Such efforts have intensified with their growing need for workers and globally rising demand in the sector. Involvement in the teaching process and other forms of co-operation with educational institutions has represented a key recruitment channel in the case of ESET, complemented by direct marketing efforts.

Second, during the period between the late I980s and early 2000 s the Czech Republic and Slovakia were characterized by a lack of available funding for high-risk, technologically innovative companies. The absence of venture capital, angel financing or even exit through a functioning IPO/stock market flotation meant that growth had to be financed either by foreign direct investment (FDI) or retained earnings. A lack of available finance for innovative firms pushed the available human capital towards companies that could succeed in a more gradual way and finance their expansion from retained earnings. Consequently, one of the reasons explaining the success of the antivirus firms was the long product development cycle and the fact that they were ready when the time for global expansion came. From this perspective, we can see limited availability of financial resources for home-grown software companies and limited foreign investment in the late I980 and I990s as a contributing factor helping to explain why technical talent was steered towards the antivirus industry, and also why a particular business model was chosen by two out of the three firms under study.

To gain a first-mover advantage, one of the imperatives of business success is to lock in a sufficient number of users to gain incumbency in the market. The availability of funding to finance this rapid expansion is therefore frequently a crucial condition of market success. Lack of finance significantly contributed to the development of a by-now successful freemium business model, as the decision to introduce this model was based on a shortage of available financing for paid marketing (cf. Bell, 
I995). However, what has spurred marketing innovation in AVAST and AVG has been detrimental for other types of innovative businesses in these countries.

\section{Demand conditions and domestic market}

Our conceptualization of the importance of demand conditions does not correspond directly to Porter's or Bhidés emphasis on the importance of domestic markets in terms of sophisticated demand and 'venturesome' consumers. The Czech and Slovak consumers and overall antivirus markets do not appear to be in any way more sophisticated, advanced or experiment-prone during the I990s than elsewhere. Porter's conceptualization of the home base more generally, however, fits the intricacies of the Czech and Slovak antivirus industry very well. First, even after extensive internationalization, what unites the three companies is that the R\&D bases for core products and often also their offshoots are maintained in the home countries. This is linked to the importance of the domestic market, which was crucial for all three companies in terms of product testing, income generation and international recognition. The second feature of the domestic market, obvious in retrospect, was the unattractiveness of the region in terms of the early entry of private equity and foreign investors. This enabled a period of shielded growth for domestic firms and also protected them from the pressure to consolidate evident throughout the segment worldwide.

\section{Firm strategy, structure and rivalry, related and supporting industries, and geographical proximity}

Even though the firms are competitors, their interaction has remained collegial rather than destructive, which has been facilitated by a number of supporting conditions to which we have alluded (market segmentation and the availability of the workforce). We did not identify clusters of joint suppliers or consumers, or intensive flows of human capital between the firms. There is no geographical proximity that one associates with traditional clusters (e.g. Emilia-Romagna, Silicon Valley, Boston Route I28): Prague, Brno and Bratislava are the three largest cities in former Czechoslovakia, with their own metropolitan economies, spanning more than 320 kilometres from Prague to Bratislava (with Brno in the middle). The firms were created independently of each other, not as spin-offs, and they have had an informal agreement not to poach staff. The firms effectively recruit in one Czechoslovak market and the exclusivity of employees creates one of the most contentious areas of interaction (e.g. IO-20 per cent of developers in AVAST are Slovak by nationality). There is an indication of relationships between the top managers/founders of the companies, bound together also by what several interviewees called 'the antivirus ethos of the profession'. On a more practical level, companies assist each other in the exchange of virus samples. Overall, owing to a tendency to choose different business models and target groups, though AVG and AVAST appear to be direct competitors, a tacit 'nonaggression pact' between the firms has been established. In other words, while spatial proximity did not seem to matter (Prague is much further from Bratislava than either Vienna or Budapest), we identified the importance of social proximity. Boschma and Frenken (20I0) conceptualize social proximity as socially embedded relations i.e. involving trust that is based on friendship, kinship and experience through repeated interaction. Agarwal et al. (20I0) use patent data to demonstrate that spatial and 
social proximity are substitutes in their influence on access to knowledge. Our results confirm that social proximity can replace geographical proximity in stimulating knowledge spillovers. They also show the various mechanisms through which it can have an impact.

\section{The role of government and additional factors}

The success of the three antivirus companies has happened without any governmental support or direct intervention. The journey to the first league occurred 'in spite of' and not 'because of' state policies and the existing institutional environment. Stakeholders identified a range of areas that represent barriers in their businesses, from conservative immigration policies and barriers to the integration of a foreign workforce, a lack of highly-skilled staff, poor law enforcement, unstable and inflexible business codes to widespread corruption. Continued access to qualified human capital might become a limit on growth, and governments have been slow in facilitating a closer connection between business and academia, especially in the Slovak context.

We would also highlight a range of 'chance' or unexpected consequence factors that contributed to firms' success. The first is linked to the importance of the spread of the internet, which coincided with the time during which the firms were ready to expand to global markets with (by then) top quality products. That is, when the opportunity came, the three firms were ready to take it and to do so with different sales and marketing models to gain first-mover advantages in their respective client markets. The concomitant spread of internet technology is what made the freemium model a very successful business strategy and granted access to a critical mass of end-users. The second aspect is the unexpected consequence of the poor image of the post-communist region as seen by foreign ICT investors and the underdeveloped financial infrastructure and private equity market characteristics of transition economies in the I990s. Combined, these factors effectively resulted in an environment with a lack of foreign competition or private equity entry that had elsewhere led to the acquisition of home-grown firms. Domestic firm rivalry and aspects of tacit cooperation at the same time created productive competition, which stimulated product improvements.

\section{Conclusion}

Using Porter's framework for the competitive advantage of nations as an organizing concept, this article has studied factors underlying the global success of the antivirus industry in the Czech Republic and Slovakia. By gathering rich empirical data through semi-structured interviews with various stakeholders and combining these with existing research about the characteristics and growth of the IT sector more generally, we have been able to see the sector from different perspectives. We have found that a set of country-level factors and successful firm strategies have interacted with external conditions in a positive way to foster the global success of the antivirus industry.

Porter's 'diamond' framework of national competitive advantage was not fully confirmed by our investigation, but we find a range of factors proposed by him important. For AVAST, AVG and ESET, the existence of a home base was important in two key respects: access to high quality human resources with technical skills and, paradoxically, a lack of finance. Firm rivalry and strategies have also been important, 
but mainly within the broader context of global technological change, especially the spread of internet access. On the other hand, we have found no or very limited evidence of the role of geographical proximity, supporting and related industries or sophisticated domestic consumers in the successful development of the industry. Social proximity, however, mattered in complex ways.

Porter's framework, mainly focused on large advanced economies, cannot provide a complete framework for considering the extensive level of internationalization experienced by these firms. As they grew, they underwent not only internationalization of markets but also of management and ownership. In two out of the three companies, internationalization has been comprehensive and has resulted in the recruitment of international CEOs and several board members and an international IPO. Nonetheless, they have remained firmly tethered to their home bases in Prague, Brno and Bratislava, where both management and core R\&D remain located. In other words, even in such small countries and in such a globalized industry, the continuing existence of a 'parochial' home base is perfectly possible, but it paradoxically requires willingness to internationalize in other ways.

The second finding that goes beyond Porter's framework concerns how not just availability but also constraints can positively shape competitive advantage. The availability of the domestic expertise and technical skills as a legacy of the communist regime in Czechoslovakia granted the key competitive advantage of the Czech and Slovak firms. A lack of available finance for innovative firms pushed the available human capital towards companies that could succeed in a more gradual way and finance their expansion from retained earnings. While the availability of capital is key for most products, including software, the long product development cycle of antivirus software and the incremental innovation needed for its success meant that this environment was favourable for this segment. The existence of a period of sheltered growth in the domestic market, which was an unexpected consequence of a lack of FDI, helped to stimulate the growth and development of the domestic sector.

The respective governments played a marginal role in this process, which took place without their direct support or intervention, and in spite of weaknesses in the legal and business environments and other barriers. This finding, together with the positive impact of the absence of foreign capital investment in the sector during the I990s, is in stark contrast to the prevalent understanding of the key positive role played by governments in shaping the pathways of Central Europe's transition and integration into world markets.

\section{Acknowledgements}

The authors would like to acknowledge the support of NEUJOBS, a research project funded by the European Union $7_{\text {th }}$ Framework Programme for Research and Development (www.neujobs.eu), grant agreement No. 266833.

\section{Notes}

I Czechoslovakia was a part of the Soviet bloc until I989 and broke up at the end of 1992 into the Czech Republic (Io million inhabitants) and Slovakia ( 5 million inhabitants). Both countries have been members of the European Union since 2004 .
2 Based on usage data for security applications on Microsoft Windows systems.

3 We use the term 'IT sector' interchangeably with 'software industry'. In the statistics, it is typically defined by NACE 72 group (Rev. I) or NACE 
JC $(62+63)($ Rev. 2) - computer and related activities - which includes hardware consultancy, the publishing of software, other software consultancy and supply, data processing, database activities, maintenance and repair of office, accounting and computing machinery, and other computerrelated activities. The IT sector defined in this way is only a subpart of the broader ICT sector, which includes both manufacturing (electronics, office equipment, telecommunication equipment) and ICT services (IT, telecommunications, postal services, radio and TV broadcasting) (Guzik \& Micek, 2008).

4 Examples in the Czech Republic include investments of Sun Microsystems/Oracle, Red Hat, SolarWinds and NetSuite, and in Slovakia of Alcatel Lucent and the NESS Kosice Development Centre.

5 Examples include Sun Microsystems acquiring NetBeans (Němeček, 1999) and Microsoft Slovakia acquiring Caligari (I-3).

${ }^{6}$ In the subsequent text, we use the current name for all of the firms to avoid confusion.

7 According to a regional investor in the sector who bought a share in AVG in 200I, a merger of the three companies was discussed and suggested by the capital owners, but there was no will on the part of the company founders to pursue it nor was there the financial necessity to do so.

8 For example, an AVG product was strong in the UK market because it offered a free version very early on, while AVAST has a strong presence in France because of the ability to provide its product in French following the SanDisc alliance.

9 A brief question in the context of our argument concerns why the antivirus industry did not grow in a similar way elsewhere. Another is why it is that the eastern part of former Czechoslovakia took a rather darker route towards virus creation and criminal activity. One possible explanation relates to a combination of locational factors and the level of development in Central and Eastern Europe. In the I990s, markets in nearby Austria and Germany provided opportunities for the legal employment of IT professionals. In addition, a somewhat higher level of purchasing power enabled the creation of markets for software, which further encouraged legal activities rather than illegal endeavours.

\section{References}

Agarwal, A. \& Pandey, A. 2004. The Next Big Opportunity: Moving Up the Value Chain — From BPO to KPO. Evalueserve. <http://www.asiapacificdirect.com.au/big_opportunity_moving_up_the_value_chain per cent2oper cent2ofrom_bpo_to_kpo.pdf>.

Agarwal, A., Kapur, D. \& McHale, J. 2008. How do spatial and social proximity influence knowledge flows? Journal of Urban Economics, 64: 258-69.

Andacky, J. 2004. In ESET until Retirement. (V Esete až do dôchodku). Trend, 3 June. <http://www.etrend.sk/ trend-archiv/rok-/cislo-/v-esete-az-do-dochodku.html>.

Andacky, J. 2009. Šéf Esetu: Niet dôvery na Internete. Trend, 8 December. <http://firmy.etrend.sk/firmynefinancny-sektor/sef-esetu-niet-dovery-na-Internete.html>.

Bassanini, A. \& Ernst, E. 2002. Labour market regulation, industrial relations and technological regimes: A tale of comparative advantage. Industrial and Corporate Change, II(3): 39I-426.

Bell, J. I995. The internationalization of small computer software firms: A further challenge to stage theories. European Journal of Marketing, 29(8): 60-75.

Benner, C. 2002. Work in the New Economy: Flexible Labour Markets in Silicon Valley, Vol. 5. Oxford: Wiley-Blackwell.

Bernaciak, M. \& Šcepanovic, V. 20Io. Challenges of upgrading: The dynamics of East Central Europe's integration into European automotive production. Industrielle Beziehungen-Zeitschrift fuer Arbeit, I7(2): I23-I46.

Bhidé, A. 2008. The Venturesome Economy: How Innovation Sustains Prosperity in a More Connected World. Princeton, NJ: Princeton University Press.

Bohle, D. \& Greskovits, B. 2007. The state, internationalization, and capitalist diversity in Eastern Europe. Competition \& Change, II(2): 89-II5.

Bohle, D. \& Greskovits, B. 20I2. Capitalist Diversity in Europe's Periphery. New York: Cornell University Press.

Boschma, R. 2005. Proximity and innovation: A critical assessment. Regional Studies, 39(I): 6I-74.

Boschma, R. \& Frenken, K. 20I0. The spatial evolution of innovation networks: A proximity perspective. In: R. Boschma \& R. Martin, eds. Handbook of Evolutionary Economic Geography. Cheltenham: Edward Elgar.

Capik, P. \& Drahokoupil, J. 20II. Foreign direct investments in business services: Transforming the Visegrád Four region into a knowledge-based economy? European Planning Studies, I9(9): I6II-3I.

Clancy, P., O'Malley, E., O'Connell, L. \& Van Egeraat, C. 200I. Industry clusters in Ireland: An application of Porter's model of national competitive advantage to three sectors. European Planning Studies, 9(I): 7-28. 
Coe, N. 1997. Internationalisation, diversification and spatial restructuring in transnational computer service firms: Case studies from the UK market. Geoforum, 28(3-4): 253-70.

Čapek, D. 20I2. Národní programme reforem opomíjí důležitost oblasti ICT, zejména služeb s vysokou přidanou hodnotou. Press release, 28 March. <http://www.cianews.cz/tiskove-zpravy-press/narodni-program-reforemopomiji-dulezitost-oblasti-ict-zejmena-sluzeb-s-vysokou-pridanou-hodnotou/>.

Davies, H. \& Ellis, P. 2000. Porter's competitive advantage of nations: Time for the final judgement? Journal of Management Studies, 37(8): I189-2I4.

Duman, A. \& Kureková, L. 20I2. The role of the state in development of socio-economic models in Hungary and Slovakia: The case of industrial policy. Journal of European Public Policy, I9(8): I207-28.

Enright, M. J. 2003. Regional clusters: What we know and what we should know. In: J. Bröcker et al., eds. Innovation Clusters and Interregional Competition. Berlin: Springer, pp. 99-I29.

Gereffi, G. I994. The organization of buyer-driven global commodity chains: How US retailers shape overseas production networks. In: G. Gereffi \& M. Korzeniewicz, eds. Commodity Chains and Global Capitalism. Westport, CT: Praeger, pp. 95-I22.

Grimes, S. 2006. Ireland's emergence as a centre for internationally traded services. Regional Studies, 40(9): IO4I-54.

Grimes, S. \& White, M. 2005. The transition to internationally traded services and Ireland's emergence as a successful European region. Environment and Planning A, 37(I2): 2169-88.

Guzik, R. \& Micek, G. 2008. The impact of delocalisation on the European software industry. In: L. Labrianidis, ed. The Moving Frontier: The Changing Geography of Production in Labour-intensive Industries. Aldershot: Ashgate.

Hall, P. A. \& Soskice, D. W. eds. 200I. Varieties of Capitalism: The Institutional Foundations of Comparative Advantage. Oxford: Oxford University Press.

Hardy, J., Sass, M. \& Fifekova, M. P. 20I . Impacts of horizontal and vertical foreign investment in business services: The experience of Hungary, Slovakia and the Czech Republic. European Urban and Regional Studies, I $8(4): 427-43$.

Hidalgo, C. A. \& Hausmann, R. 2009. The building blocks of economic complexity. Proceedings of the National Academy of Sciences, I06(26): 10570-75.

Jarosova, G. 2008. ESET attracted by abroad, its owners by vision (ESET láka cudzina, jeho majitel’ov vízie). Trend, 2 October. <http://technologie.etrend.sk/technologie/eset-laka-cudzina-jeho-majitelov-vizie.html>.

Kočí, P. 20I2. [Steve] Jobs' dead end jobs (Jobsové slepých uliček). Respect, 20 May. $<$ http://respekt.ihned.cz/cI55852030 -jobsove-slepych-ulicek>.

Komárek, M. 2008. AVAST! antivirus from Strašnice. Respect, 23 December. <http://respekt.ihned.cz/cI-36390580avast-antivirus-from-strasnice>.

Koubský, P. 2000. Old tricks for new economy (Staré triky pro novou ekonomiku). Respect, I9 June. <http:// respekt.ihned.cz/cI-36108560-stare-triky-pro-novou-ekonomiku>.

Lauder, S. 20Iо. Brno, full of brains (Brno, mozků plno). Respect, 5 December. <http://respekt.ihned.cz/cI48451980-brno-mozku-plno>.

Micek, G. 2008. Sticky places in the globalised economy: The role of localities in attracting the software industry. EUROPA XXI, I9: 169-82.

Microsoft. 2003. Microsoft to acquire antivirus technology from GeCAD software. <http://www.microsoft.com/ en-us/news/press/2003/juno3/o6-Iogecadpr.aspx>.

Myant, M. \& Drahokoupil, J. 20Iıa. International integration, varieties of capitalism, and resilience to crisis in transition economies. <http://papers.ssrn.com/sol3/papers.cfm?abstract_id=I744726>.

Myant, M. \& Drahokoupil, J. 2orrb. Transition Economies: Political Economy in Russia, Eastern Europe, and Central Asia. Hoboken, NJ: Wiley-Blackwell.

Němeček, T. I999. Brain for a half billion (Mozek za půl miliardy). Respect, I November. <http://respekt.ihned. cz/cI-36108340-mozek-za-pul-miliardy>.

Nölke, A. \& Vliegenthart, A. 2009. Enlarging the varieties of capitalism: The emergence of dependent market economies in East Central Europe. World Politics, 6I(4): 670-702.

OPSWAT. 20I2. Security Industry Market Share Analysis, March 20I2. <http://billmullins.wordpress. com/2OI2/o3/I2/opswats-march-20I2-security-industry-market-share-analysis/>.

Orfanus, D. 20I2. How does freemium pay off? (Ako sypú grátis služby?) Trend, I8 April. <http://www.etrend. sk/trend-archiv/rok-20I2/cislo-I5/ako-sypu-gratis-sluzby.html>. 
Pavlínek, P., Domański, B. \& Guzik, P. 2009. Industrial upgrading through foreign direct investment in Central European automotive manufacturing. European Urban and Regional Studies, I6(I): 43-63.

Piech, K. \& Radosevic, S. eds. 2006. The Knowledge-based Economy in Central and Eastern Europe. New York: Palgrave Macmillan.

Porter, M. E. I990. The competitive advantage of nations. Harvard Business Review, March-April. <http:// kkozak.wz.cz/Porter.pdf>.

Respect. 2000. The Czech Republic now too small for Grisoft, therefore expanding to the USA (Česko je již pro Grisoft př́liš̌ malé, proto expanduje v USA). Respect, II October. <http://hn.ihned.cz/cI-777264-cesko-je-jizpro-grisoft-prilis-male-proto-expanduje-v-usa>.

Rugman, A. M. \& D'cruz, J. R. I993. The double diamond model of international competitiveness: The Canadian experience. MIR: Management International Review, 33: I7-39.

Sass, M. \& Fifekova, M. 20II. Offshoring and outsourcing business services to Central and Eastern Europe: Some empirical and conceptual considerations. European Planning Studies, I9(9): I593-609.

Singer, S. \& Senor, D. 20I r. Start-up Nation: The Story of Israel's Economic Miracle. Toronto, ON: McClelland \& Stewart.

SME. 2008. Investors in Slovakia lack qualified workforce (Investorom na Slovensku chýba kvalifikovaná pracovná sila), 24 February. <http://ekonomika.sme.sk/c/3745216/investorom-na-slovensku-chyba-kvalifikovanapracovna-sila.html>.

Smith, A. J. 20I2. The competitive advantage of nations: Is Porter's diamond framework a new theory that explains the international competitiveness of countries? Southern African Business Review, I4(I): I05-30. $<$ http://www.ajol.info/index.php/sabr/article/view/76358>.

Toner, P. 20II. Innovation and vocational education. Economic and Labour Relations Review, 2I(2): 75.

Třešńk, P. 2007. Globalisation is in love with Prague. Respect, I4 September. <http://respekt.ihned.cz/cI36338250 -globalisation-is-in-love-with-prague>.

Tsai, Y., Lin, J. Y. \& Kurekova, L. 2009. Innovative R\&D and optimal investment under uncertainty in high-tech industries: An implication for emerging economies. Research Policy, 38(8): I388-95.

White, M. C. 2004. Inward investment, firm embeddedness and place. European Urban and Regional Studies, II (3): $243-60$.

Wickham, J. \& Bruff, I. 2008. Skills shortages are not always what they seem: Migration and the Irish software industry. New Technology, Work and Employment, 23(I-2): 30-43.

\section{Notes on contributors}

Miroslav Beblavý is a Senior Research Fellow at CEPS and Associate Professor of Public Policy at the Comenius University, Bratislava, Slovakia. Between 2002 and 2006 he was the State Secretary of the Ministry of Labour, Social Affairs and Family in Slovakia. Dr Beblavý gained his PhD at the University of St Andrews. His areas of interest include employment and social policy, education policy, fiscal policy, governance and corruption. He has published in various international journals, including Public Administration, Europe-Asia Studies, Public Administration and Development of Party Politics.

Lucia Mýtna Kureková, PhD, is Senior Researcher at the Slovak Governance Institute (SGI), Bratislava and a recurrent Visiting Lecturer in the Public Policy Department of the Central European University (CEU), Budapest. She earned her doctoral degree in political science from the CEU in 20II. Her research focuses on the areas of labour migration and labour mobility; labour markets, skill formation and education systems; and industrial, economic and social policy. She has published in various international journals, including European Journal of Public Policy, Journal of Common Market Studies and East European Politics and Societies.

Correspondence to: Miroslav Beblavý, Kopernikova 47, 82104 Bratislava, Slovakia. Email: beblavy@governance.sk 